\title{
18. A New Occurrence of Fossiliferous Gotlandian Limestone on Yokokura-yama, Ógiri-mura, Takaoka-gun, Kôti-ken.
}

\author{
By Hisakatsu YaBe and Toshio SugrYama. \\ (Comm. by H. YABE, M.I.A., Feb. 12, 1942.)
}

\begin{abstract}
About thirty years ago, the senior author collected a small block of limestone containing Favosites from a stream bed near Yugyôzi ${ }^{1}$, on the lower course of the Yugyôzi-gawa (river), a right tributary of the Niyodo-gawa that empties into Tosa-wan (bay). The recent discovery of fossiliferous Gotlandian deposits in the Kitakami Mountainland ${ }^{2)}$ led the writers to suspect the occurrence of a similarly aged formation somewhere near Yugyôzi. In the meantime Mr. T. Kobayashi, Assistant-Professor of the Institute of Geology, Tokyo Imperial University, informed the writers of his discovery of a limestone bearing Halysites at Imose, Kusaka-mura, Takaoka-gun, Kôti-ken (Prefecture) ${ }^{3}$, situated about $15 \mathrm{~km}$ east of Yugyôzi. Although the limestone containing Halysites occurs there only as a small mass, constituting a member of a formation of green phyllitic rock with occasional interbeddings of chert, and rather limited in extension, this reported find encouraged the writers to persist in expecting the find, as just stated, of a similar fossiliferous deposit near Yugyôzi, inasmuch as the limestone of Imose greatly resembles in general aspects that containing Favosites from Yugyôzi.

As to the limestone of Imose, although the manner in which the fossils are preserved by no means renders their detection easy, whether in the field or for microscopical examination in the laboratory, the junior writer who visited this locality, following Mr. Kobayashi's instructions, succeeded in obtaining a number of corals and bryozoas, sufficiently well preserved for generic and to a certain extent for specific determination. His subsequent study ${ }^{4)}$ in the laboratory has shown that this limestone contains, besides Halysites, many others, including such forms as
\end{abstract}

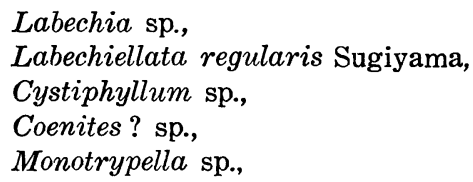

all of which are specifically identical with those found in the Kawauti fauna of the Kitakami Mountainland. Regarding these material, he

1) 由(遊)行寺.

2) H. Yabe and T. Sugiyama: Preliminary Report on the Fossiliferous Gotlandian and Devonian Deposits newly discovered in the Kitakami Mountainland. This Proc. Vol. XIII, 1937. T. Sugiyama: Stratigraphical and Palaeontological Studies of the Gotlandian Deposits of the Kitakami Mountainland. Sci. Rep. Tôhoku Imp. Univ., 2nd Ser. (Geol.), Vol. XXI, No. 2, 1940.

3) 高知縣高岡郡日下村妹脊.

4) T. Sugiyama: Correlation of the Gotlandian Deposits of China and Japan. Jour. Geol. Soc. Japan, Vol. LVIII, No. 573. p. 295, 1941. 


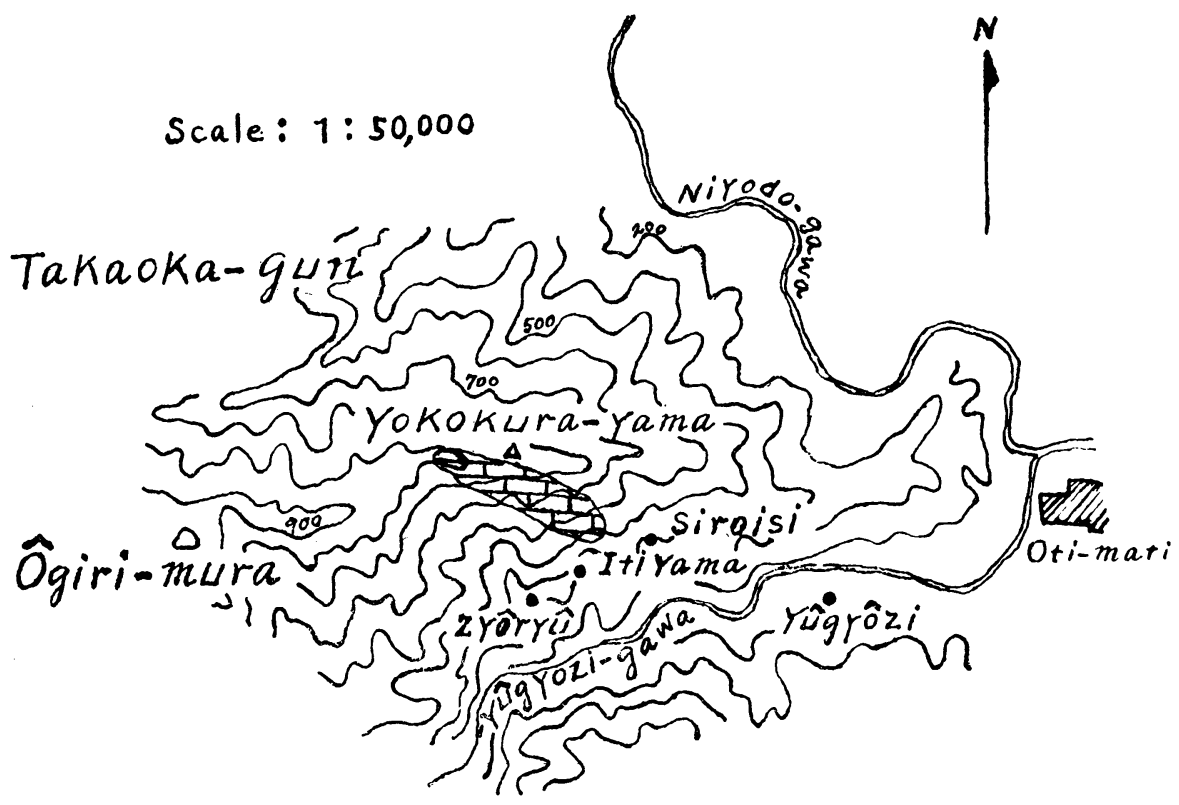

Fig. 1. Map showing the distribution of the Gotlandian Yokokurayama limestone.

expressed the view that the Imose and Kawauti faunas, with similar constituents, are approximately contemporaneous.

At the request of his senior, the junior writer, this winter vacation, led a party of students of the Institute of Geology and Palaeontology, Tóhoku Imperial University, on a trip to this promising field on the northwestern border of the Sakawa ${ }^{1)}$ basin, Kôti-ken, and succeeded in finding a richly fossiliferous limestone near the top of Yokokura-yama ${ }^{2}$, northwest of the small village Yugyôzi, which lies in a valley of the same name.

Oti-mati ${ }^{3)}$, which is a town of Takaoka-gun, at the junction of the Niyodo-gawa and Yugyôzi-gawa, lies in the northwesternmost part of the Sakawa basin, so familiar to Japanese geologists through the writings of Edmund Naumann ${ }^{4}$, published early in the Meizi era. Yokokura-yama forms a ridge, $774.8 \mathrm{~m}$ high, of E-W trend, $4 \mathrm{~km}$ due west of Oti-mati. The limestone, which will hereafter be called the Yokokurayama limestone, extends for more than $1 \mathrm{~km}$, SES to WNW, dipping $70^{\circ} \mathrm{NNE}$. It is well exposed at the heads of the three small left side-valleys of the Yugyôzi-gawa, on the southern slope of Yokokura-yama, each with the small villages of Siraisi, Itiyama, and Zyôryu $\hat{u}^{5)}$, respectively, naming from east to west. Farther westward, this limestone extends to near the top of the mountain ridge.

1) 佐川.

2) 横倉山.

3) 越智町.

4) E. Naumann und M. Neumayr: Zur Geologie und Palaeontologie von Japan. Denksch. d. K. Akad. Wiss., mat.-nat. Kl., Bd. LVII, 1890.

5) 白石·市山・上流. 


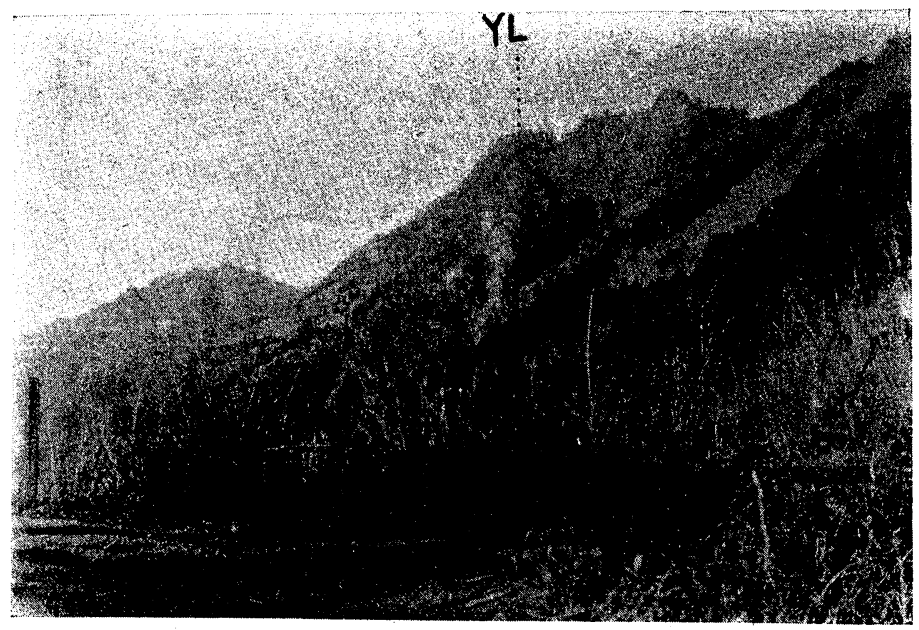

Fig 2. Yokokura-yama from west; YL.-Yokokurayama limestone.

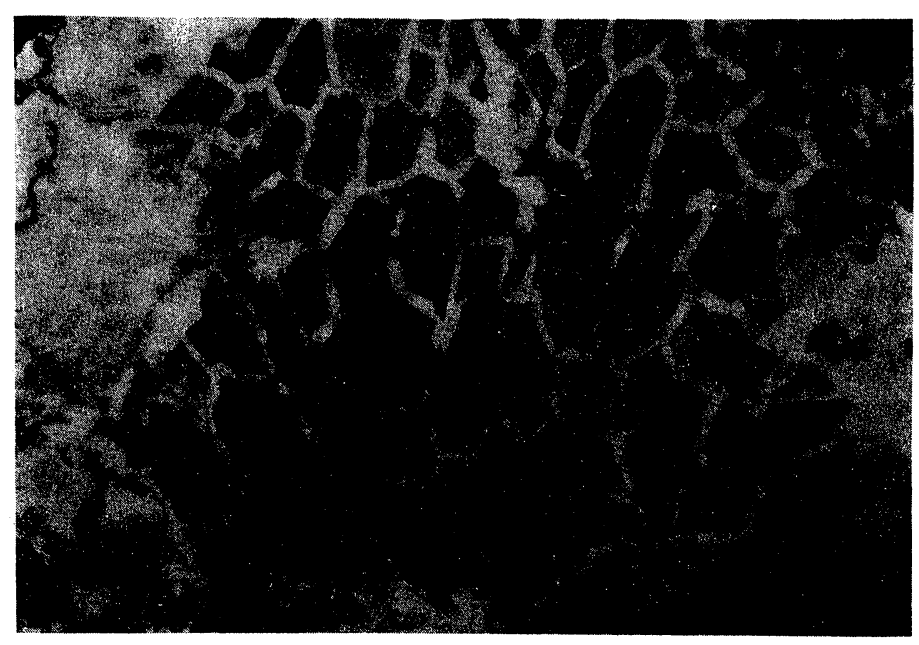

Fig. 2. Halysites in transverse section; $\times 2$.

The Yokokurayama limestone, which is $200-300 \mathrm{~m}$ thick, is overlain by a series of greenish or gray chert replete with radiolarian remains, and also a greenish chert with tuffaceous substance or siliceous tuffite, of unknown thickness, and underlain successively by a well banded red chert with abundant radiolarian remains, $1.5 \mathrm{~m}$ thick, a greenish or gray chert also rich in radiolarian remains, $50 \mathrm{~m}$ thick, and lastly by a graywacke sandstone, somewhat metamorphosed, with layers of a green phyllitic rock, of unknown thickness.

A dislocation line-the western prolongation of the Kuroiwa ${ }^{1)}$ thrust of Mr. Kobayashi-runs approximately NE-SW across the middle part of the above mentioned three side-valleys and separates this Older Palaeozoic complex of limestone, chert, and phyllitic rock at the north of it from the Middle and Lower Cretaceous sedimentaries at the south.

1) 黑岩. 
The Yokokurayama limestone is grayish white, mottled in the lower part with a reddish chert- a siliceous tuffite-like substance. It is in parts so crystalline as to be called a marble, and in others less crystalline. It is in the last mentioned part that the fossils, namely, tabulates, tetracorals, brachiopods, etc. abound in good condition.

of the megascopic fossils contained in the limestone, Halysites predominates, followed by Favosites in frequency; while tetracorals and brachiopods are also abundant. Although no stromatoporoids are visible to the unaided eyes, they may probably be detected with the microscope. The abundant occurrence of Halysites in this limestone proves it to be Gotlandian, seeing that this genus is developed best in that geological age, though it already appeared in the later Ordovician and survived to the earliest Devonian. The Favosites first found in the limestone block collected by the senior writer, and also common in the new collection, exhibits rather archaeic features characteristic of those from formations older than the Devonian.

The Imose limestone with Halysites is likewise grayish white, mottled, with a reddish substance, and crystalline. It forms, reported by Kobayashi and Iwaya ${ }^{1)}$, a small mass in a complex of greenish phyllitic rock or sheared sandstone. In addition, the junior writer of the present paper noticed at the locality just mentioned a greenish-gray chert in association with phyllitic rock. This complex of phyllitic rock, chert, and limestone, comprising the Imose formation of Messrs Kobayashi and Iwaya, which occupies only a very limitted area on the northern border of the Sakawa basin, thrusts on the sedimentaries of the Monobegawa or Ryoseki series, on the southern side, and showing igneous contact with granitic rock on the north. Imose is situated some $10 \mathrm{~km}$ due west of Oti-mati. There is every evidence for concluding that the Imose and Yokokurayama limestones belong to one and the same formation.

1) T. Kobayashi and Y. Iwaya: Discovery of the Halysites-bearing Imose Limestone in the Northeastern Part of the Sakawa Basin in Tosa and the Geology of that Part of the Basin. Journ. Geol. Soc. Japan, Vol. XIJVII, No. 565, 1940. 